\title{
A Study on the Institutional Mechanism of Improving Rural Party Members and Cadres to Serve the Masses
}

\author{
Zhao Kai \\ Marxism School of Northwest Minzu University, Lanzhou, 730030, China
}

Keywords: Village, Party members and cadres, Maintain ties with the masses, Serve the masses, Institutional mechanism.

\begin{abstract}
Maintaining close ties with the masses is one of the Party's fine traditions and styles. It is of uppermost priority to directly serve the masses and keep the flesh-and-blood relation between party and masses of the people for the rural party members and cadres. In the new situation, we must improve the normal mechanisms to serve the masses for the rural party members and cadres, including establishing and improving the mechanism of theory learning and education for the rural party members and cadres, establishing and improving the working mechanism of investigation and research at the basic level for the rural party members and cadres, establishing and improving the working mechanism of serving the masses for the rural party members and cadres and building a long-term mechanism of public opinion expression and rights protection.

The report of the 18th CPC National Congress pointed out: "party members and cadres should be directly linked to the mass system.". Insisting on asking the government for the people, asking for the people, asking for help from the people, and drawing wisdom and strength from the great practice of the people. Insist on hard work, hard work and prosperous people, dare to explore, dare to play, do more to make people satisfied with the good things". Close ties with the masses is one of the fine traditions and three styles of the party, and a notable symbol of the Chinese Communist Party's distinction from other political parties. The party since eighteen, the CPC Central Committee with Comrade Xi Jinping as the core also attaches great importance to the work of the masses, the general secretary Xi Jinping stressed: "always adhere to the fundamental purpose of serving the people wholeheartedly, our party has always been the fundamental reason of people's support and love, is essential for the full play of the advantages of Party's close ties with the masses. At any time we must put the interests of the people in the first place, and make it a starting point and a foothold for all our work to realize, maintain and develop the fundamental interests of the overwhelming majority of the people".
\end{abstract}

Enhance the Recognition of Necessity and Importance of the Institutional Mechanism of Rural Party Members and Cadres to Serve the Masses

Party members and cadres in rural areas to serve the people is the priority among priorities of our party has been working, especially Chinese rural population accounted for more than half of the total population, the peasants issue has been Chinese and the Chinese Communist Party need to face and solve the problem, which requires party members and cadres in rural areas will be in close contact with the masses of the excellent service style and in specific work will continue to carry forward its development into normalization institutionalized activities, and make sure the masses are thinking, anxious masses, people trapped in the solution. It is necessary for us to further explore the mechanism of rural Party members and cadres to contact the service of the masses to protect and practice path, mechanism normalization institutionalized system to explore and establish a set of Party members and cadres in rural areas better and more effectively to contact the service of the masses.

Decisive Stage of Completing the Building of a Moderately Prosperous Society in all Respects. The party with Comrade Xi Jinping as the core of leadership of the CPC Central Committee of the National People's is moving to a comprehensive well-off society, comrade Deng 
Xiaoping of "well-off" has had such a vivid explanation, he said a well-off society is not rich but life easier, "three rural issues" has been a priority among priorities Chinese Communist Party work that agriculture is the foundation of the national economy, but in rural areas compared to urban development lags behind, the income of the farmers is still a huge gap between urban residents, therefore, is a comprehensive well-off society depends largely on whether the real well-off farmers. The Party Central Committee with Comrade Xi Jinping as the core for the full implementation of the comprehensive well-off, precise poverty, this means we need to ensure the appropriate institutional mechanisms, especially the rural Party members and cadres should better serve the people to contact, to really understand the people, people, to help people out of poverty and go off the road, this is the Communist Party of China in the new historical stage of the construction of the party and the historical stage of the mass work of the historical mission and load.

Maintaining Close Ties with the Masses is Party's Fine Tradition and Style. The public attitude for or against related to the success or failure of the party. Since the date of the establishment of the Communist Party of China insist and carry out everything for the masses, all rely on the masses, from the masses, to the masses line, today Chinese China people through the leadership of the Communist Party of nearly one hundred years of time, we can still see the Chinese Communist Party will this fine tradition and style, continue to maintain the inheritance and carry forward.

During the period of new democratic revolution, the leadership of the Communist Party of Chinese China people to realize national democratic revolution is always with people especially in close contact with the farmers, the revolutionary base areas and the Anti-Japanese base has been established in the poor and backward rural poor and backward rural areas, although not rich in natural resources, not superior living conditions, but the Communist Party Chinese always will be stationed in the rural revolutionary base is because there are people most profound, this is because the Communist Party Chinese know farmer problem is the central issue China revolution. The initial stage of socialist construction since the founding of new China, Chinese in the development stage, the leadership of the Communist Party of China poor and blank "five year plan Chinese people to realize the development of economic construction is still together with the masses, to the masses of the people, rely on the masses of the people. Since the reform and opening up, the Party Central Committee has further shifted the focus of work to economic construction. As the foundation of the national economy, agriculture still relies heavily on the people, and for the people, it is necessary to solve the problem of people's food and clothing. Since the eighteen years of the party, the goal of the great rejuvenation of the Chinese nation, the Chinese dream and the "two one hundred years" have been achieved, and the people of the whole country will have to work hard for such a great dream. It can be seen that the great achievement of the leadership of the Communist Party of China China people in revolution, construction, reform and development in the course of history is always has close ties with the masses, from the masses of the people, from people could never achieve such great success, always in close contact with the masses is the party's fine tradition and political advantage.

There are Many Realistic Problems in the Practice of Serving the Masses for the Rural Party Members and Cadres under the New Situation. Since the 18th CPC National Congress, the general secretary Xi Jinping's people's livelihood thought always put people in the highest position, at the same time on mass work there are many important expositions, he once said: "in the face of the new situation and new tasks, to be good at study and grasp the characteristics and laws of mass work, a new method of work, the work of the masses to do deep meticulous work of the masses, enhance the affinity and appeal, improve the pertinence and effectiveness of the work of the masses".

Perfect the system of rural Party members and cadres to contact the service of the masses is a pressing matter of the moment, this is because the long-term since the rural grassroots party's mass line practice there are many realistic problems, these realistic problems began forced rural Party cadres direct contact and serve the people development activities must be normalized system. The rural grass-roots party's mass line practice mainly has the following problems: one is the lack of active security system sound mechanism, arbitrariness, normalization and poor effectiveness, the villagers' committee is directly elected by villagers self-management, self-education and self-service and self-supervision of the grass-roots mass self-government organizations. The lack of security 
mechanism, a sense of discipline and rules consciousness is not strong, which leads to the rural Party members and cadres to carry out mass work at random, normal and poor timeliness; two is the number of Party members and cadres of the activities of the ideological understanding there is a tendency for some simple and superficial, there is lack of planning, the problem of insufficient innovation consciousness in specific work, activities lead to alienation, this fine tradition of a part of the rural Party members and cadres of the mass line and close ties with the masses. General enough, do not go to the countryside and the masses, resulting in only a mere formality; three is the number of Party members and cadres "people skills" activities is not enough, lack the necessary capacity to support the rural Party members and cadres generally political quality, ideological quality, knowledge and ability are of low quality, working methods of direct contact and serve the masses and the main task of knowing is not enough, leading to contact and serve the masses always want to stay in the level and not be implemented; the four is the economic foundation of some local activities is weak, lack of the necessary material basis, especially the economic basis of the central and western rural areas and even some weak areas in the no poverty stage, close contact and serve the masses not only have the ideological and spiritual care guide, but also need the appropriate material support and help.

\section{Countermeasures and Suggestions of Improving Institutional Mechanism to Serve the Masses for the Rural Party Members and Cadres}

Establish and Improve the Mechanism of Theory Learning and Education for the Rural Party Members and Cadres. The first step is to improve the rural Party cadres on the activities of thinking, which requires us to put the rural Party members and cadres of the ideological construction in the first place, and strengthen the learning is the basic channel of rural Party cadres ideological construction. The ideological and political quality and the knowledge quality of Party members and cadres in rural areas are on the low side, especially the lack of theoretical study of Party members and cadres from the peasants, and there is not enough knowledge about the practice of "connecting and serving the masses". Therefore, establishing and perfecting the rural Party cadres theory education mechanism, has important theoretical significance to improve the rural Party members and cadres of the ideological and political quality of close ties with the masses of the practice of thinking and understanding, is a strengthening of Marx's theory of knowledge education, make the rural Party cadres to further understanding of the Marx doctrine is the basic guiding idea for our party made China; the two is to strengthen the study on the party's theory, route and policy, so that party members and cadres in rural areas of new ideas and new concepts of the new strategy to further clarify the party under the new situation of governance, in order to be able to act according to regulations in specific work; three is to enhance the rural Party cadres ideological cultivation, ideological cultivation of Party members in rural areas the cadre is low, reflected in the specific work is only consider their own interests while ignoring the interests of the people, thinking and understanding is not enough, Ideological training and standing are low, which needs to further enhance the ideological cultivation of Party members and cadres in rural areas.

Establish and Improve the Working Mechanism of Investigation and Research at the Basic Level for the Rural Party Members and Cadres. Mao Zedong once said: "no investigation, no right to speak", "no correct investigation also has no right to speak, to really think people are thinking, anxious masses, people trapped in the solution, we need rural Party cadres honestly go to rural deep into the masses launched related research and visit, it is necessary to establish and improve the rural grass-roots party members and cadres working mechanism research. The rural working life of Party members and cadres at the grassroots and rural Party cadres often grassroots research has no inevitable relation, some party members and cadres in rural areas has not really carried out primary research, in the specific work just empty talk, did not listen to people, which requires the Party cadres in the countryside village home, resolve and eliminate people's sense of distance and strangeness, even need to reshape the image of Party members and cadres in rural areas in the masses of Party members and cadres to enhance credibility, the image represents the image of the party, to ensure the good thing to do, doing well. Rural Party members and cadres should also pay attention to the specific 
methods to carry out the work of the masses, and to enhance their ability to work, aging makes contact and serve the people better, on this basis, leading cadres should play an exemplary role, prompting more leading cadres of the Party grassroots especially research more backward economy and problems. Listen to the opinions of the masses, understand the aspirations of the masses, to help resolve the difficulties.

Establish and Improve the Working Mechanism of Serving the Masses for the Rural Party Members and Cadres. It is necessary for us to further establish and improve the service mechanism of the rural Party members and cadres serving the masses as a practical activity and a scientific theoretical support and methodological system. Establish and improve the rural Party members and cadres to serve the people working mechanism, we should improve the service mechanism, especially in the weak infrastructure in rural areas, to further promote grassroots agencies and departments of farmers' service level, we should establish the convenience of the masses, to understand public opinion platform and carrier, passive service, secondly should further clarify the countryside the responsibility of Party members and cadres, so that each party cadres clear responsibilities, in order to further improve the efficiency of serving the masses, and the masses of Party members and cadres to avoid you push me on this situation, in addition to township and village cooperatives to establish rural Party cadres contact point system for units in the rural areas, each party cadres to contact a fixed a village and to the point, so you can make more contact and serve the people of pertinence and effectiveness, Finally, can make full use of emerging media, especially the network expansion work of the masses, leveraging the network public opinion, actively promote, guide and organize the masses to optimize the network politics environment, strengthen the network to effectively guide and manage politics, network criticism and network monitoring.

Build a Long-Term Mechanism of Public Opinion Expression and Rights Protection. Rural Party members and cadres close contact and serve the masses of two-way, in the process of contacting and serving the masses of Party members and cadres and masses timely expression of public opinion and interests is a two-way interaction, therefore, to respect the people's principal position, build long-term mechanism to protect the rights and interests of the expression of public opinion. Close contact and serve the masses, establish long-term mechanism to protect the expression of public opinion and interests, we should listen to public opinion, observing the people, to know and respect the people's voices and demands, which requires the government to establish an open and transparent mechanism, people should have the right to know enough, secondly, establish correct understanding of letters and visits of the channel accordingly, we should encourage the masses to actively understand and participate in government decision-making, the government's policy and policy initiatives have better advice or opinion can take the right way through reasonable channels to express their demands, especially to broaden the channels of letters and visits, the implementation of online admissibility of the petition system, improve the smooth and orderly convenient and efficient demands of expression, this is also the masses believe that the party believes that the government's performance, but also participate in the exercise of the right to know, A method of power and supervision, which embodies the requirements of democratic governance, must not regard the masses' letters and visits as an additional burden and an unstable factor affecting the construction of a harmonious society.

\section{Acknowledgements}

This research was the result of the project named "A Study on the Institutional Mechanism of Perfecting the Rural Party Members and Cadres' Directly and Serving the Masses”, which was supported by the Fundamental Research Funds for the Central Universities of Northwest Minzu University (Grant No. 31920140023). 


\section{References}

[1] Dai Anlin. The Party s Mass Line Education Practice Normalization and Its System Construction [J]. Chongqing Social Sciences, 2013(6): 11-17.

[2] Wu Xing. A Comparison of Yanan Rectification and the Educational Practice of Mass Line from the Perspective of Administering the Party [J]. Journal of Guangzhou University (Social Science Edition), 2016, 15(12): 36-40.

[3] Li Jie. Marxist View of Mass and the Party's Mass Line [J]. Social Sciences in Chinese Higher Education Institutions, 2014(1): 27-39+157-158.

[4] The History of the CPC Is a History of the Shaping and Improvement of Its Mass Line [J]. Social Sciences in China, 2011, 32(4): 19-28. 